\title{
EFFECT OF ANTERIOR CROSSBITE CORRECTION ON THE QUALITY OF LIFE FOR A GROUP OF EGYPTIAN CHILDREN DURING MIXED DENTITION STAGE
}

\author{
Sherine Badawy* and Adel Rashid **
}

\begin{abstract}
Objective: Assessment of anterior crossbite correction on the quality of life of children between 8-10 years using the Child Perceptions Questionnaire $\left(\mathrm{CPQ}_{8-10}\right)$.

Methods: Seventy children, 8-10 years, seeking treatment for anterior dental crossbite, were selected for this clinical study. The impact of early interceptive orthodontic treatment of anterior dental crossbite on the children's oral health related quality of life (OHRQoL) was evaluated using the Brazilian version of the Child Perceptions Questionnaire $\left(\mathrm{CPQ}_{8-10}\right)$, in two different points in time: T0: Before treatment of anterior dental crossbite and T1: After correction of anterior crossbite.

Results: The overall score of the $\mathrm{CPQ}_{8-10}$ and the scores of each health domain (subscale) of the children of both sexes decreased significantly after final treatment $(\mathrm{p}<0.001)$. For the overall score and all heath domains (subscales) except emotional wellbeing subscale, there was no significant difference between the scores of both genders $(p>0.05)$. At the first appointment, females had a significantly higher score of emotional wellbeing than males $(p<0.001)$.
\end{abstract}

Conclusion: Early interceptive orthodontic treatment of children with anterior dental crossbite is essential to improve their OHRQoL.

\section{INTRODUCTION}

There is a growing interest in the influence of oral health and facial esthetics on the quality of life of children and adolescents. ${ }^{(1)}$ Oral health is crucial for good quality of life; it has an impact on children's feeding, smiling, speaking, and socializing. ${ }^{(2)}$ Facial appearance influences self-esteem and emotional well-being, playing an important role in social interaction and affecting the child's quality of life. ${ }^{(3)}$ Oral-health-related quality of life (OHRQoL) has been used as a measure of the influence of oral conditions and esthetics on quality of life ${ }^{(4)}$.

Anterior crossbite malocclusion is considered a major esthetic problem and refers to a condition in which there is a change in the inclination of one or more anterior teeth, with the maxillary incisors

\footnotetext{
* Lecturer of Pediatric Dentistry, Faculty of Dentistry, Fayoum University.

** Lecturer of Orthodontics, Faculty of Dentistry, Fayoum University.
} 
positioned lingually in relation to the mandibular anterior teeth. ${ }^{(5)}$ The incidence of anterior crossbite reported in the literature worldwide - depending on the age of the child, ethnic group, and methods of registration - ranges from $0.5 \%$ to $11.9 \%$. $^{(5,6,7,8)}$

Anterior crossbite could be dental, skeletal, or functional. Etiological factors include trauma, supernumerary teeth, crowding, lip biting, presence of odontomas, over-retained, and necrotic or delayed exfoliation of the primary incisors. ${ }^{(9,10)}$ Since it is seldom self-corrected, it should be treated as soon as possible, ${ }^{(5)}$ otherwise it could develop into a more severe malocclusion or cause traumatic injury to the periodontal tissues or temporo-mandibular joint (TMJ)..$^{(8,11)}$

Several treatment options such as; removable and/or fixed appliances, which act directly on the malpositioned teeth have been advised for early interceptive treatment of anterior crossbites. ${ }^{(12)}$

Moreover, anterior crossbite is associated with higher levels of dissatisfaction with appearance and may cause a negative impact on oral health- related quality of life (OHRQoL) of children. ${ }^{(13)}$ Several methods of assessing the OHRQoL of children are available such as Child Perceptions Questionnaire (4\&14), Child-Oral Impacts on Daily Performance (Child-OIDP) ${ }^{(15)}$, Early Childhood Oral Health Impact Scale (ECOHIS) ${ }^{(16)}$, and Child Oral Health Quality of Life Questionnaire (COHQoL) ${ }^{(17)}$.

The Child Perceptions Questionnaire CPQ, assesses the children's perceptions regarding the impact of oral health on quality of life. There are three versions of the CPQ, one for each specific age groups: 6-7, 8-10 and $11-14$ years..$^{4,14 \& 18}$

Therefore, the aim of this study was to assess the impact of early interceptive orthodontic treatment in the mixed dentition stage to correct the anterior dental crossbite on the quality of life of children between 8-10 years using the Brazilian version of the Child Perceptions Questionnaire (CPQ8-10). ${ }^{19}$

\section{SUBJECTS AND METHODS}

\section{1-Subjects:}

\section{Sample size calculation:}

A power analysis was designed to have adequate power to apply a 2-sided statistical test of the oral health related quality of life following interceptive orthodontic treatment of anterior crossbite in a group of Egyptian children in the mixed dentition stage.

According to the results of Abreu et al..$^{20}$ in which the $(M e a n \pm S D)$ values social well-being scores at baseline was $(2.52 \pm 3.21)$ and after treatment

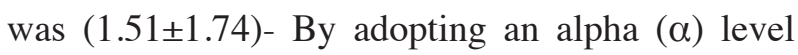
of $0.05(5 \%)$, a Beta $(\beta)$ level of $0.20(20 \%)$ i.e. power $=80 \%$, and an effect size (d) of (0.362); the predicted sample size (n) was found to be a total of (62) cases. Sample size was increased to 70 cases to compensate for possible dropouts. Sample size calculation was performed using $\mathrm{G}^{*}$ Power version 3.1.9.4. ${ }^{(21)}$

\section{Children:}

Seventy children ( 38 males and 32 females) in the age range of 8-10 years seeking treatment for anterior dental crossbite, were selected for this clinical study, from the outpatient clinic of the Pediatric Dentistry and Orthodontic Departments, Faculty of Dentistry, Fayoum University, Egypt. The study was conducted between September 2017 and January 2019.

\section{Inclusion criteria:}

- Children in early mixed dentition stage, age 8 to 10 years, with at least one or more maxillary incisors in palatal crossbite relationship.

- Full eruption of the four first permanent molars.

- Class I molar relationship according to Angle classification.

- Class I skeletal relationship.

- Cooperative children and parents. 


\section{Exclusion criteria:}

- History of orthodontic treatment.

- Anterior skeletal or functional crossbite.

- Posterior crossbite associated with anterior crossbite.

- Presence or history of any oral habits.

- Presence of any systemic diseases.

\section{2- Methods:}

The research proposal was submitted to and approved by the Ethics Committee of the faculty of Dentistry, Fayoum University. The aim and clinical procedure of the study were explained to the children and their parents/guardians and that their participation was entirely voluntary. A written consent was obtained from the children who agreed to participate in the study, as did their parents/guardians.

\section{Clinical examination and treatment procedure:}

A detailed case history (including personal, past and present medical history, as well as, dental history) and comprehensive oral examination and panoramic radiograph for each child were recorded. A full mouth treatment was carried out for each child before starting the interceptive orthodontic treatment.

The treatment plan for the anterior crossbite consisted of an interceptive orthodontic treatment with removable plates and screw, provided that there was sufficient mesiodistal distance to move the upper tooth labially. Impressions of both arches were taken using alginate and study models made with plaster. The removable appliance was manufactured using acrylic resin, bilateral occlusal coverage of the posterior teeth, and an anterior expansion screw. Figure (1).

The protrusion screw was activated twice per week $(0.5 \mathrm{~mm})$ until normal incisor overjet was achieved. The patients were instructed firmly to wear the appliance day and night, except for meals, tooth brushing, and physical activities. The children and their parents/guardians were given instruction on diet restrictions and oral hygiene measures. This information was emphasized again on subsequent monthly appointments. The progress was evaluated every 4 weeks, until dental crossbite correction was achieved. Figure (2 and 3)

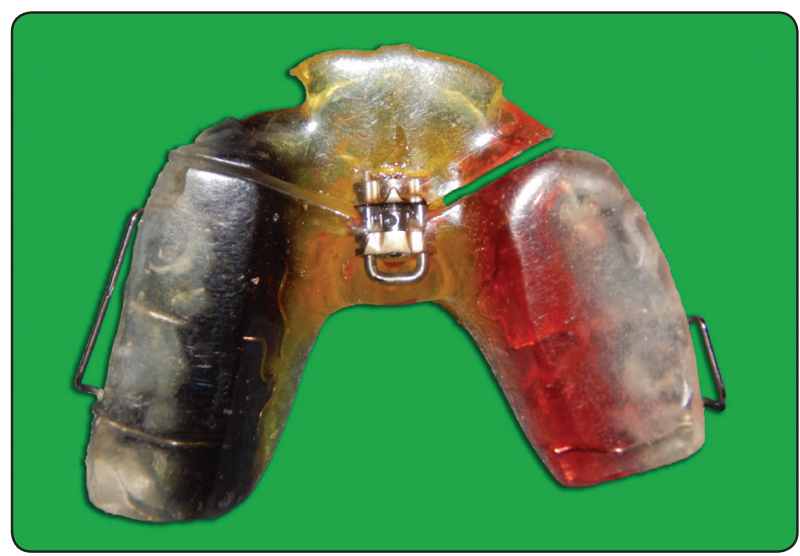

Fig. (1): The applince used for correction of Anterior cross bite.

During the follow-up period, patients whose anterior dental crossbite had not been fully corrected, due to lack of cooperation or compliance to wearing the removable appliance were subjected to another treatment plan or orthodontic appliance.

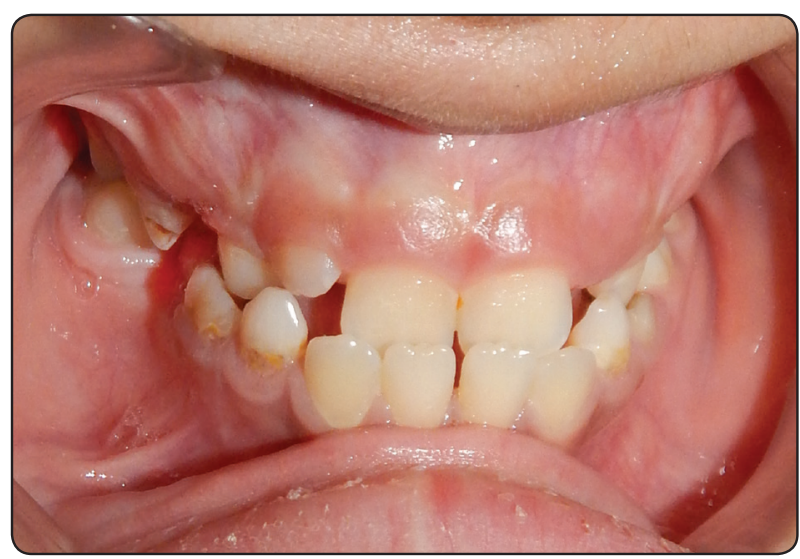

Fig. (2) : Anterior cross bite malocclusion before treatment. 


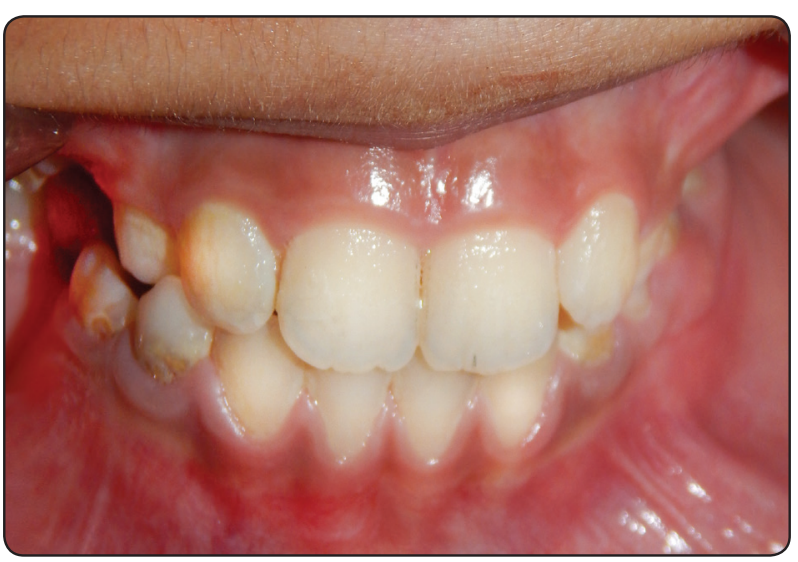

Fig. (3) : Occlusion after correction.

\section{OHRQoL Assessment tool:}

The impact of the anterior crossbite on the children's OHRQoL was measured using the Brazilian version of the Child Perceptions
Questionnaire $\left(\mathrm{CPQ}_{8-10}\right) \cdot{ }^{19}$ It consists of 25 items divided into 4 health domains (subscales): oral symptoms (OS) with 5 questions, functional limitations (FL) with 5 questions, emotional wellbeing (EW) with 5 questions and social well-being (SW) with 10 questions. An ordinal scale provides the following response options for each question: never (0), once/twice (1), sometimes (2), often (3), and every day/almost every day (4). The scores for each subscale are computed by adding up the scores for each question.

The OHRQoL was evaluated using the $\mathrm{CPQ}_{8-10}$ in two different points in time: T0: Before placing the removable appliance for determining the baseline and T1: After correction of anterior crossbite. Figure (4)

\begin{tabular}{|c|c|c|c|c|c|c|c|c|c|c|}
\hline \multirow[b]{3}{*}{ O } & \multirow{2}{*}{\multicolumn{2}{|c|}{\begin{tabular}{|l} 
Patient 1 \\
Gemder : \\
Age:
\end{tabular}}} & \multirow{2}{*}{\multicolumn{2}{|c|}{$\begin{array}{l}\text { Patient 2 } \\
\text { Gender : } \\
\text { Age: }\end{array}$}} & \multicolumn{2}{|c|}{$\begin{array}{l}\text { Patient 3 } \\
\text { Gender : } \\
\text { Ape : }\end{array}$} & \multicolumn{2}{|c|}{$\begin{array}{l}\text { Patient 4 } \\
\text { Gender : }\end{array}$} & \multirow{2}{*}{\multicolumn{2}{|c|}{$\begin{array}{l}\text { Patient } 5 \\
\text { Gemder: } \\
\text { Age: }\end{array}$}} \\
\hline & & & & & Age: & T 1 & Age: & T 1 & Age : & \\
\hline \multirow{3}{*}{\multicolumn{11}{|c|}{$\begin{array}{l}\text { Toothache } \\
\text { Mouth sores }\end{array}$}} \\
\hline & & & & & & & & & & \\
\hline \multirow{3}{*}{\multicolumn{11}{|c|}{$\begin{array}{l}\text { Pain upon ingesting cold } \\
\text { food trapped in teeth } \\
\text { Food then }\end{array}$}} \\
\hline & & & & & & & & & & \\
\hline \multirow{2}{*}{\multicolumn{11}{|c|}{$\begin{array}{l}\text { Food trapped in teeth } \\
\text { Bad smell in mouth }\end{array}$}} \\
\hline & & & & & & & & & & \\
\hline \\
\hline \multirow{2}{*}{\multicolumn{11}{|c|}{$\begin{array}{l}\text { Time for Eating } \\
\text { Difriculty biting and/or } \\
\text { chewing }\end{array}$}} \\
\hline \multirow{2}{*}{\multicolumn{11}{|c|}{$\begin{array}{l}\text { Difficulty eating } \\
\text { Trouble talking } \\
\end{array}$}} \\
\hline & & & & & & & & & & \\
\hline \multirow{2}{*}{\multicolumn{11}{|c|}{$\begin{array}{l}\text { Difficulty sleeping } \\
\text { Emotional Wellbeing }\end{array}$}} \\
\hline & & & & & & & & & & \\
\hline \multicolumn{11}{|c|}{$\begin{array}{l}\text { Bothered } \\
\text { Sad }\end{array}$} \\
\hline \multicolumn{11}{|l|}{ Sad } \\
\hline \multicolumn{11}{|l|}{$\begin{array}{l}\text { Ashamed } \\
\text { Worried }\end{array}$} \\
\hline \multirow{2}{*}{\multicolumn{11}{|c|}{ Nice }} \\
\hline & & & & & & & & & & \\
\hline \multicolumn{11}{|l|}{ Child Missed School } \\
\hline \multicolumn{11}{|c|}{\begin{tabular}{l|} 
Trouble doing homework \\
Trouble paying attention
\end{tabular}} \\
\hline \multicolumn{11}{|c|}{$\begin{array}{l}\text { in class } \\
\text { Child avoided smiling or } \\
\text { laughing }\end{array}$} \\
\hline \multicolumn{11}{|c|}{$\begin{array}{l}\text { Child avoided takking } \\
\text { Child Avoided other } \\
\text { Children }\end{array}$} \\
\hline \\
\hline \multicolumn{11}{|c|}{$\begin{array}{l}\text { Victim of name-calling } \\
\text { Questions about teeth }\end{array}$} \\
\hline \multirow{2}{*}{\multicolumn{11}{|c|}{ 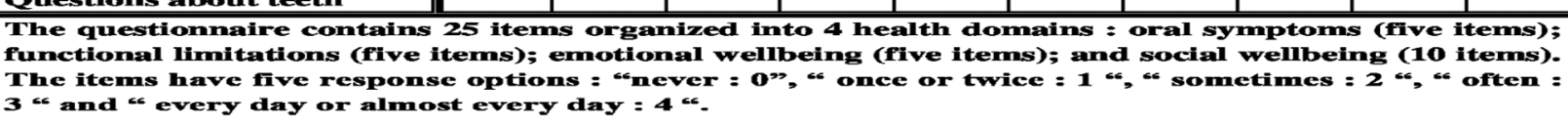 }} \\
\hline & & & & & & & & & & \\
\hline $\begin{array}{l}\text { Never } \\
\text { o }\end{array}$ & Once & irtwic & & $\underset{2}{\text { ometim }}$ & & ften & Ever: & yday & & \\
\hline
\end{tabular}

Fig. (4) : The Brazilian version of the CPQ8-10 


\section{Statistical analysis:}

Categorical data were presented as frequencies and percentages and were analyzed using chi square test. Numerical data were presented as mean, standard deviation (SD), median and range values. They were explored for normality by using Kolmogorov-Smirnov and Shapiro-Wilk tests. Parametric data of age were analyzed using independent t-test. Ordinal data of $\mathrm{CPQ}_{8-10}$ scores were analyzed using Wilcoxon signed rank test for comparison between different time points and Mann-Whitney $U$ test for comparisons between the scores of different genders. The significance level was set at $\mathrm{P} \leq 0.05$ within all tests. Statistical analysis was performed with IBM ${ }^{\circledR}$ SPSS $^{\circledR}$ Statistics Version 26 for Windows.

\section{RESULTS}

Seventy Children with the mean age of $(8.63 \pm 1.08)$ participated in this study, $38(54.3 \%)$ were males with the mean age of $(8.76 \pm 1.05)$ and $32(45.7 \%)$ were females with the mean age of $(8.47 \pm 1.11)$. Figure (5)
1- The overall score of the $C P Q_{8-10}$ and the scores of each health domain (subscale) of the children of both sexes decreased significantly after final treatment $(\mathrm{p}<0.001)$. Table (I).

2- At the first appointment, females [(13.47 \pm 2.05$)$, $14.00(9.00)]$ had a significantly higher scores of "Emotional wellbeing" than males [(11.32 \pm 2.37$)$, $11.00(9.00)](\mathrm{p}<0.001)$. Table (II).

3- For the overall score and all heath domains (subscales), there was no significant difference between the scores of both genders $(\mathrm{p}>0.05)$. Table (II).

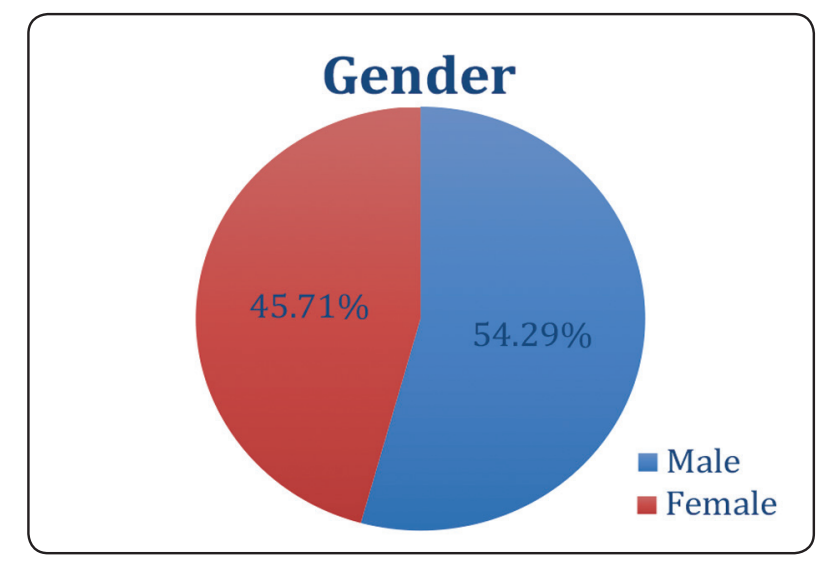

Fig. (5) : Bar chart showing gender of participants.

TABLE (I) : Mean \pm standard deviation (SD), median and range values for $\mathrm{CPQ}_{8-10}$ scores:

\begin{tabular}{|c|c|c|c|c|c|}
\hline \multirow{2}{*}{ Health domains } & \multicolumn{2}{|c|}{ First appointment $\left(\mathbf{T}_{0}\right)$} & \multicolumn{2}{|c|}{ After finalized treatment $\left(T_{1}\right)$} & \multirow{2}{*}{ p-value } \\
\hline & Mean \pm SD & Median (Range) & Mean \pm SD & $\begin{array}{l}\text { Median } \\
\text { (Range) }\end{array}$ & \\
\hline Oral symptoms & $5.33 \pm 1.97$ & $6.00(9.00)$ & $0.81 \pm 1.05$ & $0.00(5.00)$ & $<0.001 *$ \\
\hline Functional Limitations & $9.44 \pm 1.92$ & $9.00(10.00)$ & $2.09 \pm 1.19$ & $2.00(5.00)$ & $<0.001 *$ \\
\hline Emotional Wellbeing & $12.30 \pm 2.46$ & $12.00(10.00)$ & $6.60 \pm 1.78$ & $6.00(10.00)$ & $<0.001 *$ \\
\hline Social Wellbeing & $18.73 \pm 5.59$ & $18.00(25.00)$ & $5.80 \pm 3.15$ & $5.00(14.00)$ & $<0.001 *$ \\
\hline Overall score & $45.80 \pm 7.69$ & $46.00(31.00)$ & $15.30 \pm 4.51$ & $15.00(21.00)$ & $<0.001 *$ \\
\hline
\end{tabular}

*; significant $(p \leq 0.05)$ 
TABLE (II) : Mean \pm standard deviation (SD), median and range values for CPQ8-10 scores in different genders :

\begin{tabular}{|c|c|c|c|c|c|c|}
\hline \multirow{2}{*}{$\begin{array}{c}\text { Health } \\
\text { domains }\end{array}$} & \multirow[b]{2}{*}{ Gender } & \multicolumn{2}{|c|}{ First appointment $\left(\mathrm{T}_{0}\right)$} & \multicolumn{2}{|c|}{ After finalized treatment $\left(T_{1}\right)$} & \multirow[b]{2}{*}{ p-value } \\
\hline & & Mean \pm SD & $\begin{array}{l}\text { Median } \\
\text { (Range) }\end{array}$ & $\operatorname{Mean} \pm$ SD & $\begin{array}{l}\text { Median } \\
\text { (Range) }\end{array}$ & \\
\hline \multirow{2}{*}{$\begin{array}{c}\text { Oral } \\
\text { symptoms }\end{array}$} & Male & $5.50 \pm 1.96^{\mathrm{A}}$ & $6.00(9.00)$ & $0.87 \pm 1.19^{\mathrm{A}}$ & $0.00(5.00)$ & $<0.001 *$ \\
\hline & Female & $5.13 \pm 2.00^{\mathrm{A}}$ & $6.00(7.00)$ & $0.75 \pm 0.88^{\mathrm{A}}$ & $0.00(2.00)$ & $<0.001 *$ \\
\hline \multirow{2}{*}{$\begin{array}{l}\text { Functional } \\
\text { Limitations }\end{array}$} & Male & $9.55 \pm 1.93^{\mathrm{A}}$ & $9.00(8.00)$ & $2.16 \pm 1.08^{\mathrm{A}}$ & $2.00(5.00)$ & $<0.001 *$ \\
\hline & Female & $9.31 \pm 1.94^{\mathrm{A}}$ & $9.00(10.00)$ & $2.00 \pm 1.32^{\mathrm{A}}$ & $2.00(5.00)$ & $<0.001 *$ \\
\hline \multirow{2}{*}{$\begin{array}{l}\text { Emotional } \\
\text { Wellbeing }\end{array}$} & Male & $11.32 \pm 2.37^{\mathrm{B}}$ & $11.00(9.00)$ & $6.71 \pm 1.80^{\mathrm{A}}$ & $6.50(7.00)$ & $<0.001 *$ \\
\hline & Female & $13.47 \pm 2.05^{\mathrm{A}}$ & $14.00(9.00)$ & $6.47 \pm 1.78^{\mathrm{A}}$ & $6.00(10.00)$ & $<0.001 *$ \\
\hline \multirow{2}{*}{$\begin{array}{c}\text { Social } \\
\text { Wellbeing }\end{array}$} & Male & $18.08 \pm 4.94^{\mathrm{A}}$ & $17.50(20.00)$ & $6.21 \pm 2.90^{\mathrm{A}}$ & $6.00(13.00)$ & $<0.001 *$ \\
\hline & Female & $19.50 \pm 6.28^{\mathrm{A}}$ & $19.50(25.00)$ & $5.31 \pm 3.40^{\mathrm{A}}$ & $4.00(13.00)$ & $<0.001 *$ \\
\hline \multirow{2}{*}{$\begin{array}{l}\text { Overall } \\
\text { score }\end{array}$} & Male & $44.45 \pm 7.17^{\mathrm{A}}$ & $44.00(28.00)$ & $15.95 \pm 3.78^{\mathrm{A}}$ & $16.00(17.00)$ & $<0.001 *$ \\
\hline & Female & $47.41 \pm 8.09^{\mathrm{A}}$ & $48.00(30.00)$ & $14.53 \pm 5.20^{\mathrm{A}}$ & $13.00(20.00)$ & $<0.001 *$ \\
\hline
\end{tabular}

Different superscript letters indicate a statistically significant difference between genders within the same health domain*; significant $(p \leq 0.05)$

\section{DISCUSSION}

This single arm clinical trial design (no control group) was chosen over a randomized controlled trial or a case-control study due to the questionable ethics of following a group of children with pronounced malocclusions without performing any interceptive orthodontic treatment. ${ }^{(22,23)}$

This study was conducted to evaluate the effect of anterior dental crossbite correction on the quality of life in the mixed dentition stage for a group of Egyptian children depending on the hypothesis that anterior crossbite may have a negative effect on patients' quality of life, hindering their social interaction, and affecting their psychological wellbeing. ${ }^{(1,20)}$

Subjects in the current study were chosen to be in the early mixed dentition stage from 8 to 10 years old (with the mean age of $(8.63 \pm 1.08)$ because the majority of studies conducted to evaluate the impact of malocclusion on the quality of life for adolescents and young adults $(24,25,26,27)$ and a limited number were carried out in the mixed dentition stage. ${ }^{(28)}$

Since interceptive orthodontic treatment is influenced by ethnic and cultural factors with many several cross-cultural differences in the attitudes and perceptions of patients, ${ }^{(29)}$ this study was carried out on a group of Egyptian children in Fayoum governorate where different cultural factors exist and as such it contributes to the assessment of the burden of malocclusion on the quality of life.

Since during the first 6 months after fixed appliances bonding, individuals experience poorer OHRQoL in comparison to pre-treatment due to the combination of pain and discomfort with a worsening of oral symptoms and functional limitations ${ }^{(30,31)}$, removable appliances were used in the current study. 
Results regarding the change in the overall $\mathrm{CPQ}_{8-10}$ scores of all children of both sexes were statistically significant. This was in agreement with Dutra et al. ${ }^{(1)}$, Piassi et al ${ }^{(5)}$, Miamoto et $\boldsymbol{a l}^{(11)}$ and Abreu et al ${ }^{(20)}$ who concluded that children in the same age group (8 to 10 years) with malocclusions were more likely to have a negative impact on quality of life and that malocclusion treatment reduces that impact and improved quality of life .

In the current study, changes regarding oral symptoms or functional limitations scores for all the children were improved significantly. This was in agreement with Piassi et $\boldsymbol{a l}^{(5)}$ and Miamoto et $^{\boldsymbol{a l}^{(11)}}$ who also used a removable appliance in the treatment of anterior crossbite but was not in agreement with Brosens et al ${ }^{(32)}$, in which adolescents treated with fixed orthodontic appliances, experienced a significant deterioration in these aspects after 1 year of treatment.

Children in our present study experienced a significant improvement regarding the emotional and the social wellbeing subscales which was in agreement with Miamoto et.al ${ }^{(11)}$, Abreu et al (20), Brosens et al $^{(32)}$ and Seehra et.al ${ }^{(33)}$.

These findings may be related to the importance of dental esthetics and the positive effect of interceptive orthodontic therapy for the improvement of the children's OHRQoL predominantly in the dimensions of emotional and social wellbeing. ${ }^{(23,31)}$

The impact on OHRQoL is usually expected to be more significant in females than males, since males may be less self-conscious about their appearance. ${ }^{(34)}$ The findings of this study also showed that females, at the first appointment, had significantly higher scores of emotional wellbeing than males children, which is in concordance with the study done by Scapini et al. ${ }^{(35)}$ and Asokan et al ${ }^{(36)}$ which could be due to increasing centrality of peer crowd and their preoccupation with others' views of self. ${ }^{(34)}$

\section{CONCLUSION}

Anterior dental crossbite has a negative impact on the OHRQoL of the children and can compromise a child's psychosocial well-being especially female children. Thus early interceptive orthodontic treatment is essential to enhance their satisfaction with appearance and social interaction.

\section{REFERENCES}

1- Dutra SR, Pretti H, Martins MT, Bendo CB and Vale MP. Impact of malocclusion on the quality of life of children aged 8 to 10 years. Dental Press J Orthod. 2018 ;23 (2): 46-53.

2- Oliveira CM and Sheiham A. Orthodontic treatment and its impact on oral health-related quality of life in Brazilian adolescents. J Orthod. 2004; 31(1): 20-7.

3- Yusuf H, Gherunpong S and Sheiham A. Validation of an English version of the Child-OIDP index, oral health-related quality of life measure for children. Heal Qual Life Outc. 2006;4:38.

4- Jokovic A, Locker D, Stephens M, Kenny D, Tompson B and Guyatt G. Validity and reliability of a questionnaire for measuring child oral-health-related quality of life. J Dent Res. 2002 ; 81(7):459-63.

5- Eluza Piassi, Leonardo Santos Antunes, Marcia Rejane Thomas Canabarro Andrade, and Lívia Azeredo Alves Antunes .Quality of Life Following Early Orthodontic Therapy for Anterior Crossbite: Report of Cases in Twin Boys .Case Repo in Denti, vol. 2016, Article ID 3685693 , 5 pages.

6- Tausche E, Luck O, and Harzer W. Prevalence of malocclusions in the early mixed dentition and orthodontic treatment need. Euro Jo of Ortho, 2004; 26 (3) :237- 244 .

7- Go 1s EG, Vale MP, Paiva SM, Abreu MH, Serra- Negra $\mathrm{JM}$, and Pordeus IA. Incidence of malocclusion between primary and mixed dentitions among Brazilian children. A 5 year longitudinal study. Angle Orthod , $2012 ; 82(3)$ : 495-500.

8- Dimberg L, Lennartsson B, Arnrup K, and Bondemark L. Prevalence and change of malocclusions from primary to early permanent dentition: a longitudinal study. Angle Orthod , 2015; (5): 728-734. 
9- Rosa M, Lucchi P, Mariania L and Caprioglio A. Spontaneous correction of anterior crossbite by RPE anchored on deciduous teeth in the early mixed dentition. Euro $\mathrm{J}$ of Paedi Denti 2012 ; 13(3):176-80.

10- Abraham KK, James AR, Thenumkal E and Emmatty T. Correction of anterior crossbite using modified transparent aligners: An esthetic approach. Contemp Clin Dent, 2016; 7: 3947

11- Miamoto CB, Marques LS, Abreu LG and Paiva SM. Impact of two early treatment protocols for anterior dental crossbite on children's quality of life. Dental Press J Orthod.2018; 23(1):71-8.

12- Wiedel AP and Bondemark L. Stability of anterior crossbite correction: a randomized controlled trial with a 2-year follow- up. Angle Orthod ,2015; 85(2) : 189-195.

13- Rodd HD, Marshman Z, Porritt J, Bradbury J, and Baker SR. Oral health-related quality of life of children in relation to dental appearance and educational transition .Bri Dent Jo ,2011;21 ( 2), article E4.

14- Jokovic A, Locker D, Tompson B, and Guyatt MD. Questionnaire for measuring oral health-related quality of life in eight- o ten-year-old children. Pedi Dent, 2004; 26: $512-518$.

15- Gherunpong S, Tsakos G, and Sheiham A. Developing and evaluating an oral health-related quality of life index for children; The CHILD-OIDP. Community Dent Health, 2004 21(2):161-169 .

16- B. T. Pahel, R. G. Rozier, and G. D. Slade. Parental perceptions of children's oral health: The Early Childhood Oral Health Impact Scale (ECOHIS). Health Qual Life Outcomes, 2007 Jan 30;5:6.

17- Broder HL, McGrath C and Cisneros GJ. Questionnaire development: face validity and item impact testing of Child Oral Health Impact Profile. Comm Dent Oral Epide, 2007;35:8-19.

18- Jokovic A, Locker D and Guyatt G. Short forms of the Child Perceptions Questionnaire for 11-14-year-old children $\left(\mathrm{CPQ}_{11-14}\right)$ : development and initial evaluation. Health Qual Life Outcomes, 2006;4:4.

19- Martins MT, Ferreira FM and Oliveira AC. Preliminary validation of the Brazilian version of the Child Perceptions Questionnaire 8-10," Euro Jo Paed Dent, 2009;10( 3) : 135-140.
20- Abreu LG, Melgac o CA, Lages EMB, Abreu MHNG and Paiva SM. Effect of year one orthodontic treatment on the quality of life of adolescents, assessed by the short form of the Child Perceptions Questionnaire. Eur Arch Paedi Dent, 2014 ;15 (6): 435-441.

21- Faul F, Erdfelder E, Lang AG and Buchner A. "G* Power 3: A flexible statistical power analysis program for the social, behavioral, and biomedical sciences. Behav Rres Methods, 2007; 39.2 : 175-191.

22- Evans SR. Clinical trial structures. J Exp Stroke Transl Med. $2010 ; 9 ; 3(1): 8-18$.

23- Dimberg L, Arnrup K and Bondemark L. The impact of malocclusion on the quality of life among children and adolescents: a systematic review of quantitative studies. Eur J Orthod. 2015; 37(3):238-47.

24- Bernabé E and Flores-Mir C. Influence of anterior occlusal characteristics on self-perceived dental appearance in young adults. Angle Orthod, 2007; 77(5): 831-6.

25- Bernabe E, Oliveira CM and Sheiham A. Condition-specific sociodental impacts attributed to different anterior occlusal traits in Brazilian adolescents. Eur J Oral Sci, 2007; 115(6):473-8.

26- Johal A, Cheung MYH, and Marcenes W. The impact of two different malocclusion traits on quality of life. $\mathrm{Br}$ Dent J. 2007; 202(2):1-4.

27- Seehra J, Fleming PS, Newton T and DiBiase AT. Bullying in orthodontic patients and its relationship to malocclusion, self-esteem and oral health- related quality of life. J Orthod. 2011;38(4):247-56 .

28- Sardenberg F, Martins MT, Bendo CB, Pordeus IA, Paiva SM and Auad SM. Malocclusion and oral health-related quality of life in Brazilian school children A populationbased study. Angle Orthod. 2013; 83(1):83-9.

29- Josefsson E, Bjerklin K and Halling A. Self-perceived orthodontic treatment need and culturally related differences among adoles- cents in Sweden. Eur J Orthod. 2005; 27:140-7.

30- Zhang M, McGrath C and Hagg U. Changes in oral healthrelated quality of life during fixed orthodontic appliance therapy. Am J Orthod Dentofacial Orthop. 2008; 133:25-9.

31- Liu Z, McGrath C and Hagg U. Changes in oral healthrelated quality of life during fixed orthodontic appliance therapy: an 18-month prospective longitudinal study. Am J Orthod Dentofa Orthop. 2011; 139:214-9. 
32- Brosens V, Ghijselings I and Lemiere J. Changes in oral health- related quality of life reports in children during orthodontic treatment and the possible role of the steam: a follow-up study. Eur J Orthod. 2014;36: 186-91.

33- Seehra J, Newton JT and Dibiase AT. Interceptive orthodontic treatment in bullied adolescents and its impact on self-esteem and oral-health-related quality of life. Eur J Orthod. 2013; 35(5):615-21.

34- Heravi F, Farzanegan F, Tabatabaee M, and Sadeghi M. "Do malocclusions affect the oral health-related quality of life?" Oral Health and Prev Dent, 2011;9(3):229-33.

35- Scapini A, Feldens CA, Ardenghi TM, and Kramer PF. "Malocclusion impacts adolescents' oral health-related quality of life," Angle Orthod. 2013;83(3):512-8.

36- Thiruvenkadam G, Asokan S, John JB, Priya PG and Prathiba J. "Oral health-related quality of life of children seeking orthodontic treatment based on child oral health impact profile: a cross-sectional study," Contemp Clin Dent. 2015 Jul-Sep; 6(3): 396-400. 